\title{
GEOMETRIC DESIGN OF TURBO ROUNDABOUTS
}

\author{
Tamara Džambas, Saša Ahac, Vesna Dragčević
}

Subject review

Turbo roundabouts are lately a more common choice in designing multilane roundabouts. First guidelines for geometric design of this particular roundabout layout were developed by a Dutch Information and Technology Platform CROW in 2008. Soon after, a number of European countries began to develop their own regulations on turbo roundabouts, adjusted to their traffic cultures and their local conditions. In order to present the diversity of design approaches for turbo roundabout planning in various European regions, comparative analysis of turbo roundabout design procedures described in Slovenian technical specifications, Serbian design manual, German working document, and Croatian and Dutch guidelines is made. Relevant influential parameters used in these procedures are commented. Study presented in this paper may contribute to the success of turbo roundabout planning procedure.

Keywords: comparative analysis; geometric design; guidelines; influential parameters; turbo roundabouts

\section{Geometrijsko oblikovanje turbokružnih raskrižja}

Pregledni rad

Turbokružna raskrižja su u posljednje vrijeme sve češći izbor pri projektiranju višetračnih kružnih raskrižja. Prve smjernice za geometrijsko oblikovanje ovog posebnog tipa kružnog raskrižja razvijene su od strane nizozemskog istraživačkog centra CROW u 2008. Ubrzo nakon toga, nekolicina europskih zemlja započela je s razvojem vlastitih smjernica, prilagođenih njihovim prometnim navikama i lokalnim uvjetima. Kako bi se dobio uvid u raznolikost pristupa oblikovanju turbokružnih raskrižja u različitim europskim zemljama, provedena je komparativna analiza postupaka njihova oblikovanja opisanih u slovenskim tehničkim specifikacijama, srpskom priručniku, njemačkom random dokumentu, te hrvatskim i nizozemskim smjernicama. Komentirani su relevantni utjecajni parametri koji se u navedenim postupcima koriste. U radu prikazano istraživanje doprinijelo bi uspješnosti provođenja postupka geometrijskog oblikovanja turbokružnih raskrižja.

Ključne riječi: geometrijsko oblikovanje; komparativna analiza; smjernice; turbokružna raskrižja; utjecajni parametri

\section{Introduction}

A number of studies have shown that standard multilane roundabouts with concentric circulatory lanes have lower practical capacity compared to the predicted, and a frequent occurrence of traffic accidents $[1 \div 3]$. The reasons for this are high driving speeds and large number of potential conflicts at roundabout multilane entrances, exits and circulatory roadway. In the past few years road designers have been trying to solve these problems by introducing new roundabout layouts [4]. One such layout, which is used in the engineering practice (in design of new and reconstruction of existing roundabouts) in growing number of countries, is so-called turbo roundabout.

Turbo roundabout is a specially designed multilane roundabout with spiral circulatory roadway, where the traffic flows at the entrance, circulatory roadway and exit are physically separated by raised mountable lane dividers [5]. Due to the physical separation of traffic lanes, driving speed is reduced, weaving conflicts are eliminated, and sideswipe collisions at roundabout entrances and exits are prevented [2]. According to the data on web page of Dirk de Baan [6], at the moment there are 408 turbo roundabouts located in 21 countries in Europe, North and South America and South Africa. Most of them are located in the Netherlands (302), a country where this specific roundabout layout was developed, and where first turbo roundabouts were built [7]. Apart from the Netherlands, countries with a notable number of turbo roundabouts are Poland (35), Germany (11), Slovenia (11), Czech Republic (10) and Hungary (7).

In this paper geometric design of turbo roundabouts according to several European regulations is analysed. The main goal of this analysis is to point out the importance of "state of the art" approach in turbo roundabout geometric design, and to establish possible improvements of existing turbo roundabout design procedures.

\section{Background}

Previous studies conducted on turbo roundabouts [815] were mainly based on evaluation of their performances (capacity, delays), and environmental, economic and safety benefits, in regard to single-lane, standard multilane, flower and target roundabouts. Turbo roundabout geometric design was considered in a number of other studies $[1,16 \div 19]$, which were generally focused on analysis of Dutch turbo roundabout geometry and presentation of new design approaches. These new approaches, which are based on a Dutch design procedure, are described in national regulations of several European countries.

First guidelines for turbo roundabout application and design [7] were published by Dutch Information and Technology Platform CROW in year 2008. These guidelines were created on the basis of doctoral thesis of Dutch researcher dr. Lambertus Fortuijn [16]. After their release, Dutch guidelines were used not only by Dutch road designers, but also by road designers from other regions. Considering the fact that local traffic conditions and driving behaviours differ from country to country, other countries began developing their own regulations, adjusted to their driving standards, drivers' habits, and winter maintenance requirements.

Three years after Dutch guidelines were published Slovenian government released a draft version of Slovenian technical specifications on turbo roundabouts [20]. At that moment Slovenia had two roundabouts of 
this kind. In order to adjust its geometric design to local conditions, Slovenian engineers have been monitoring and determining potential problems during the roundabout construction, examining capacity and traffic safety after its implementation, and supplementing drafted specifications with new findings [21].

Another country that is intensively working on the development of turbo roundabout guidelines is Germany. In year 2010 German non-profit association FGSV, which consists of developers from various scientific and nonscientific institutions, formed a working group on turbo roundabouts. The main goal of this group is to gather information about domestic and foreign experiences with this type of roundabout, and to create German guidelines for its geometric design. In the meantime, in order to help road designers, FGSV released their draft version (published in 2013) [22]. Two years later FGSV issued an official working document on turbo roundabout use and design [23]. The final goal of FGSV working group is to improve those two documents and implement them within a German "Guidelines for the design of rural highways" (RAL) and "Guidelines for the design of urban streets" (RASt) [24].

Serbian Authority for Roads published a design manual on turbo roundabouts [25] in February 2014. Unlike the other countries with technical regulations on turbo roundabouts, Serbia has no realized turbo roundabouts yet.

Croatian guidelines for turbo roundabout use and design [26] were published in September 2014, the same month when the first turbo roundabout in Croatia was built. Two more roundabouts of this kind were constructed and opened to traffic in the city of Pula soon after.

In some other countries, such as America and Czech Republic, regulations on turbo roundabouts are still in developing phases. In American guidelines [27], only a term of turbo roundabout is given and its key features are described. With this note in their guidelines American researchers wanted to inform the US designers about this increasingly popular roundabout layout. Researchers from Czech Republic are developing a manual for turbo roundabouts under the project called "Modern turbo roundabouts and their application in design of transport constructions" [28]. This project is mostly dealing with an adjustment of turbo roundabout design to winter maintenance requirements in Czech Republic.

Comparative analysis of turbo roundabout design procedures described in Dutch [7], Slovenian [20], German [23], Serbian [25] and Croatian [26] regulations on turbo roundabouts is given below. Dutch, Slovenian and German regulations are chosen for the analysis due to the fact that these regulations origin from the countries with a notable experience in turbo roundabout design. Serbian and Croatian regulations are chosen because they are the most recent turbo roundabout regulations, which accordingly may contain some novelties in geometric design of this particular roundabout type.

\section{Review of turbo roundabout design procedures}

According to Slovenian technical specifications [20], Serbian design manual [25], German working document
[23], and Croatian [26] and Dutch [7] guidelines, geometric design of turbo roundabouts can be carried out through the following steps.

1. Selecting one of the available roundabout types.

2. Defining a relevant design vehicle.

3. Creating one of given turbo block templates.

4. Designing the remaining turbo roundabout elements.

5. Conducting design vehicle horizontal swept path analysis and fastest path vehicle speed analysis.

Despite the fact that turbo roundabout design procedures described in previous documents are quite similar, the design approach they recommend is substantially different. Major differences are shown in this chapter.

\subsection{Turbo roundabout types}

A number of different variants of turbo roundabouts can be constructed considering the planned traffic volume and capacity distribution on roundabout approaches. Main roundabout forms given in Dutch guidelines [7], Slovenian technical specifications [20] and Serbian design manual [25] are:

- Four leg variants that could also be planned as three leg variants: Egg, Basic turbo, Knee, Spiral and Rotor roundabout (Fig. 1);

- Three leg variants: Stretched-knee and Star roundabout (Fig.2).

Egg, Basic turbo, Knee, Spiral and Stretched-knee roundabout are recommended forms when one of the traffic flows is predominant. Rotor or Star roundabout forms are recommended in case of equal traffic volumes on all approaches. Other modified variants can further be designed by varying the number of entry lanes. This occurs in the Egg roundabout, which is a modified version of the Basic turbo roundabout [1].

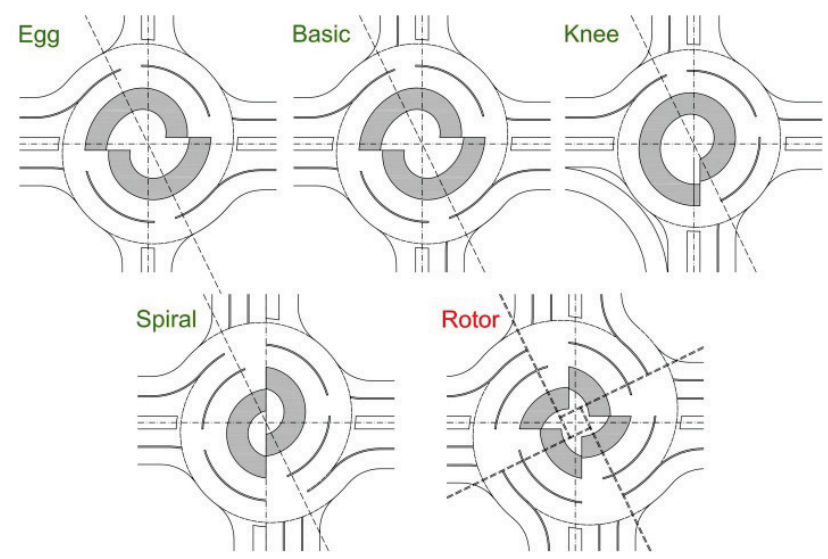

Figu $_{\text {re }} 1$ Four leg turbo roundabout variants [7, 20, 25]

In Croatian guidelines [26], reduced number of aforementioned roundabout forms is given. Those forms are: Egg, Basic turbo, Knee and Stretched-Knee roundabout. It can be noticed that all forms given in this document belong to a group of roundabouts recommended for use in a case of one dominant traffic flow. Considering the fact that [26] recommends the usage of turbo roundabouts when existing two-lane roundabouts have poor traffic safety and low capacity, and the fact that existing two-lane roundabouts often have 
evenly spread traffic volumes on all approaches, it would be advisable that variants where traffic demand is evenly spread on all approaches are also included.

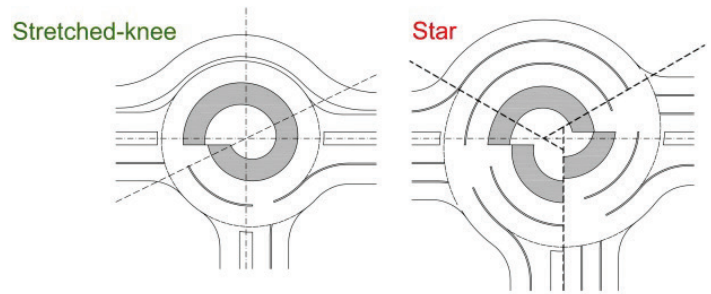

Figure 2 Three leg turbo roundabout variants [7, 20, 25]

According to German working document [23], there are maximum two traffic lanes at roundabout circulatory roadway, and several possible arrangements of entry and exit lanes on roundabout approaches (Tab. 1). Brilon [29] states that when applying one of lane combinations from Tab. 1lane changing on roundabout circulatory roadway is completely avoided. Turbo roundabout layouts that are in [23] marked as "typical layouts" are three and four leg variants of Egg, Basic turbo and Knee roundabout.

Table 1 Arrangements of entry and exit lanes on turbo roundabout [23]

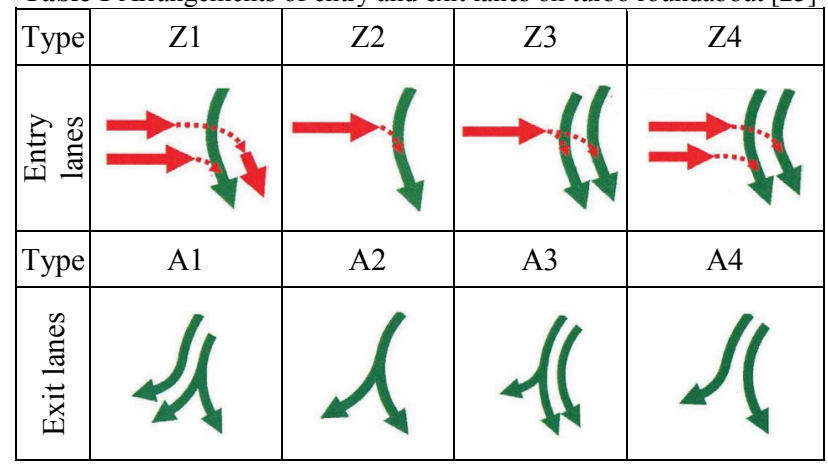

\subsection{Design vehicles}

According to all observed documents [7, 20, 23, 25, 26], turbo roundabout elements must provide unobstructed passage of the relevant design vehicle. Design vehicle and its swept path therefore have a strong influence on the turbo roundabout geometric design [19]. The choice of the design vehicle should be based on the structure of traffic flow, which significantly depends on the share of the vehicle in the vehicle fleet of the region where the roundabout is located.

Turbo roundabout templates with predetermined dimensions given in Dutch guidelines [7] are designed on the basis of the swept path of a two-axle truck with a three-axle semitrailer shown in Fig. 3 and Tab. 2. As reported in [30], two-axle truck with a three-axle semitrailer is the most commonly used vehicle combination in Europe.

In Croatian guidelines [26], dimensions for various turbo roundabout templates are provided, but it is unclear to which design vehicle they are associated with. According to Appendix D of general guidelines for roundabout design [31], relevant design vehicle on Croatian state roads is a three-axle truck with a three-axle semitrailer (Fig. 3, Tab. 2). As stated in [30], three-axle tractors are necessary to avoid overloading of the driving axle due to the high transport loads. In Croatia, this vehicle combination is still extremely rare, but in the foreseeable future it may become more frequent.

According to German working document [23], all turbo roundabout elements must be designed with regard to design vehicle swept path. Despite that requirement, relevant design vehicle for turbo roundabout design in this document is not recommended. According to German Guidelines for At-grade Intersection Design [32], relevant design vehicle on German state roads is a two-axle truck with three axle semitrailer shown in Fig. 3 and Tab. 2.

According to Slovenian technical specifications [20] and Serbian design manual [25], "when designing a turbo roundabout relevant design vehicle is usually a $16,50 \mathrm{~m}$ long truck with a semitrailer". A detailed data about Slovenian and Serbian design vehicles is available in German Guidelines for At-grade Intersection Design [32] and Serbian Technical Manual for Road Design [33] (Fig. 3, Tab. 2). Namely, in Slovenia design vehicles are not standardised, so their designers use vehicles from German regulations [34].

Design vehicle parameters that influence vehicle swept path width are: overall width $w$, length of the front overhang $t$, and length of the wheelbase $s_{2}$. As shown in Tab. 2, design vehicles considered in this paper have similar lengths of the front overhang and the wheelbase, but different overall widths: Croatian, German, Serbian and Slovenian design vehicles are $2,50 \mathrm{~m}$ wide, and Dutch $2,55 \mathrm{~m}$. Vehicle width of 2,55 $\mathrm{m}$ is an actual width of trucks with semitrailers in the catalogues of the most common vehicle manufacturers on the European market, and the maximum allowed width of motor vehicles and trailers according to Committee Directive 2002/7/EC (96/53/EC) [35]. Considering the fact that wider vehicles occupy a greater area when driving critical turning movement, i.e. that larger vehicle width leads to more stringent requirements in terms of swept path analyses, it would be advisable that widths of the design vehicles are set to $2,55 \mathrm{~m}$.

Netherlands, Germany, Slovenia, Serbia

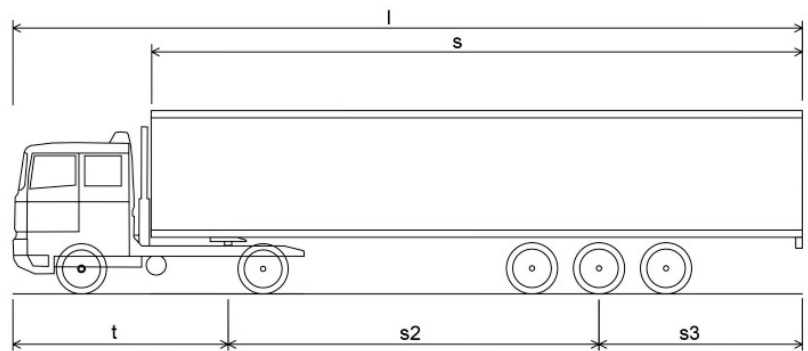

Croatia

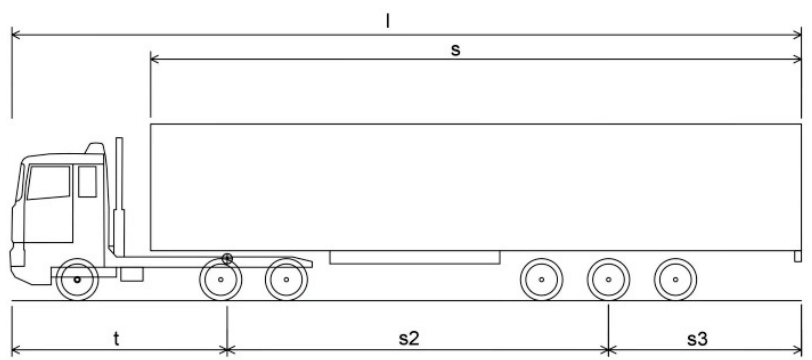

Figure 3 Dutch [7], Croatian [31], German [32], Slovenian [32] and Serbian [33] design vehicles 
Table 2 Dimensions of Dutch, Croatian, German, Slovenian and Serbian design vehicles (trucks with semitrailers)

\begin{tabular}{|l|c|c|c|c|}
\hline \multirow{2}{*}{ Element } & \multicolumn{4}{c|}{ Design vehicle } \\
\cline { 2 - 5 } & Dutch [7] & Croatian [31] & German/Slovenian [32] & Serbian [33] \\
\hline overall length $l / \mathrm{m}$ & 16,50 & 16,50 & 16,53 & 15,40 \\
\hline overall width $w / \mathrm{m}$ & 2,55 & 2,50 & 2,50 & 2,50 \\
\hline semitrailer length $s / \mathrm{m}$ & 13,60 & 13,60 & 13,61 & 12,20 \\
\hline wheelbase $s_{2} / \mathrm{m}$ & 7,80 & 7,97 & 7,78 & 7,15 \\
\hline effective rear overhang $s_{3} / \mathrm{m}$ & 4,20 & 4,03 & 4,25 & 3,75 \\
\hline front overhang $t / \mathrm{m}$ & 4,50 & 4,50 & 4,50 & 4,50 \\
\hline
\end{tabular}

\subsection{Turbo block}

A turbo block is an auxiliary construction used in turbo roundabout design [1]. Documents presented in this paper differ significantly in the way of defining the turbo block, and can be grouped as follows: documents that provide turbo block templates with predetermined dimensions (Dutch guidelines [7], Croatian guidelines [26], Slovenian technical specifications [20] and Serbian design manual [25]); documents that do not provide turbo block templates (German working document [23]).

\subsubsection{Group 1}

Turbo block for common Dutch, Croatian, Slovenian and Serbian roundabout variants (Egg, Basic turbo, Knee and Stretched-Knee roundabout) consists of four pairs of circular arcs with consecutive larger radii $\left(R_{1}, R_{2}, R_{3}, R_{4}\right)$, with centres on the line called a translation axis (Fig. 4$)$.

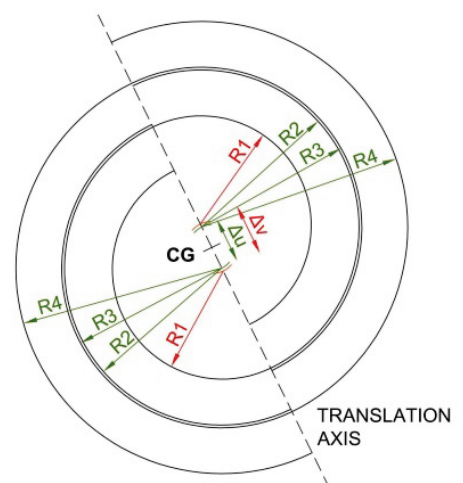

Figure 4 Turbo block elements for common Dutch [7], Croatian [26], Slovenian [20] and Serbian [25] roundabout variants

Circular arcs $R_{1}$ and $R_{2}$ represent the inner and the outer edge of the inner circulatory lane $L_{1}$, while circular arcs $R_{3}$ and $R_{4}$ represent the inner and the outer edge of the outer circulatory lane $L_{2}$. At the beginning of the inner circulatory lane $L_{1}$, widening that gradually decreases towards the lane end is performed. This widening is achieved by designing four centres of circular arcs on the translation axis: two centres on the left side of the roundabout geometric centre $\mathrm{CG}$ and two centres at the same distance on the right side of the roundabout geometric centre. Distance between the outer centres is labelled with $\Delta v$, and the distance between the inner centres with $\Delta u$. Outer centres represent the centres of the smallest circular arcs $R_{1}$, while the inner centres represent the centres of larger circular arcs $R_{2}, R_{3}$ and $R_{4}$. Physical separation of the traffic lanes is achieved by $30 \mathrm{~cm}$ wide raised mountable lane dividers, made of special concrete elements or stone granite cubes.
Dutch guidelines [7], Croatian guidelines [26], Slovenian technical specifications [20] and Serbian design manual [25] provide various turbo block templates, depending on the size of a roundabout circulatory roadway (Tab. 3).

According to Dutch guidelines [7], a turbo roundabout design should always begin by choosing a turbo block template that is most favourable from the aspect of a fastest path vehicle speed. Optimum value of the inner roundabout radius depends on the dimensions of the splitter islands on approaches. For the $3 \mathrm{~m}$ wide splitter islands the optimum value of the inner roundabout radius is $12 \mathrm{~m}$, and in a case of $7 \mathrm{~m}$ wide splitter islands this optimum value increases to15 m [1]. Application of smaller inner radii is recommended only on locations with significant spatial limitations, and the application of larger inner radii only when traffic characteristics demand it [18].

In Slovenian technical specifications [20] and Serbian design manual [25] turbo roundabout with an inner radius of $12 \mathrm{~m}$ is classified as a roundabout of "regular" size, and in Croatian guidelines [26] as a roundabout of "regular" size that is most commonly used.

As shown in Tab. 3, almost all of the dimensions given in Croatian turbo block templates differ from the dimensions of Dutch, Slovenian and Serbian turbo block templates for $5 \mathrm{~cm}$. This difference arises from different widths of outer marginal strips on circulatory roadway. On Dutch, Slovenian and Serbian turbo roundabout these strips are $45 \mathrm{~cm}$ wide ([7] also recommends a value of 40 $\mathrm{cm}$ ), and on Croatian their width is $50 \mathrm{~cm}$ (Fig. 5). Inner marginal strips are equally wide $(20 \mathrm{~cm})$, as well as circulatory lanes between the outer and the inner marginal strips.

Maximum width of circulatory lane recommended in documents from this group amounts to 5,25 m. This value represents a standard circulatory lane width on suburban single-lane roundabouts in Netherlands (turbo roundabout can be regarded as a single lane roundabout due to physical separation of traffic lanes) [36].

Turbo block should be designed in a way that circular arcs at one side of the translation axis overlap with circular arcs at the other side of the translation axis i.e. that inner circular lane at one side of the translation axis continues on the outer circular lane at the other side of translation axis [18]. Turbo block templates given in Dutch guidelines [7], Slovenian technical specifications [20] and Serbian design manual [25] do not entirely fulfil this requirement. In these templates $5 \mathrm{~cm}$ shift of circular arcs at translation axis exists (Fig. 6). In Croatian guidelines [26] this shift is eliminated by application of 5 
cm wider outer marginal strips i.e. circular arcs are overlapping on translation axis.

This group of documents provides the same instructions for translation axis positioning.
Recommended position of translation axis is clockwise "five minutes until five" for four-leg intersections (Fig. 4) and "ten past eight" for three-leg intersections.

Table 3 Dutch [7], Croatian [26], Slovenian [20] and Serbian [25] turbo block templates

\begin{tabular}{|c|c|c|c|c|c|c|c|c|}
\hline \multirow[b]{3}{*}{ Element } & \multicolumn{8}{|c|}{ Turbo roundabout template } \\
\hline & \multicolumn{2}{|c|}{ Mini } & \multicolumn{2}{|c|}{ Regular } & \multicolumn{2}{|c|}{ Medium } & \multicolumn{2}{|c|}{ Large } \\
\hline & $\begin{array}{c}\text { Dutch } \\
\text { Slovenian } \\
\text { Serbian }\end{array}$ & Croatian & $\begin{array}{c}\text { Dutch } \\
\text { Slovenian } \\
\text { Serbian }\end{array}$ & Croatian & $\begin{array}{c}\text { Dutch } \\
\text { Slovenian } \\
\text { Serbian }\end{array}$ & Croatian & $\begin{array}{c}\text { Dutch } \\
\text { Slovenian } \\
\text { Serbian }\end{array}$ & Croatian \\
\hline$R_{1} / \mathrm{m}$ & 10,50 & 10,45 & \multicolumn{2}{|c|}{12,00} & 15,00 & 14,95 & 20,00 & 19,95 \\
\hline$R_{2} / \mathrm{m}$ & \multicolumn{2}{|c|}{15,85} & \multicolumn{2}{|c|}{17,15} & \multicolumn{2}{|c|}{20,00} & \multicolumn{2}{|c|}{24,90} \\
\hline$R_{3} / \mathrm{m}$ & \multicolumn{2}{|c|}{16,15} & \multicolumn{2}{|c|}{17,45} & \multicolumn{2}{|c|}{20,30} & \multicolumn{2}{|c|}{25,20} \\
\hline$R_{4} / \mathrm{m}$ & 21,15 & 21,20 & \multicolumn{2}{|c|}{22,45} & 25,20 & 25,25 & 29,90 & 29,95 \\
\hline$L_{1} / \mathrm{m}$ & 5,35 & 5,40 & \multicolumn{2}{|c|}{5,15} & 5,00 & 5,05 & 4,90 & 4,95 \\
\hline$L_{2} / \mathrm{m}$ & 5,00 & 5,05 & \multicolumn{2}{|c|}{5,00} & 4,90 & 4,95 & 4,70 & 4,75 \\
\hline$\Delta v / \mathrm{m}$ & \multicolumn{2}{|c|}{5,75} & 5,35 & 5,30 & \multicolumn{2}{|c|}{5,15} & \multicolumn{2}{|c|}{5,15} \\
\hline$\Delta u / \mathrm{m}$ & \multicolumn{2}{|c|}{5,05} & 5,05 & 5,00 & \multicolumn{2}{|c|}{4,95} & \multicolumn{2}{|c|}{4,75} \\
\hline
\end{tabular}

Netherlands, Slovenia, Serbia
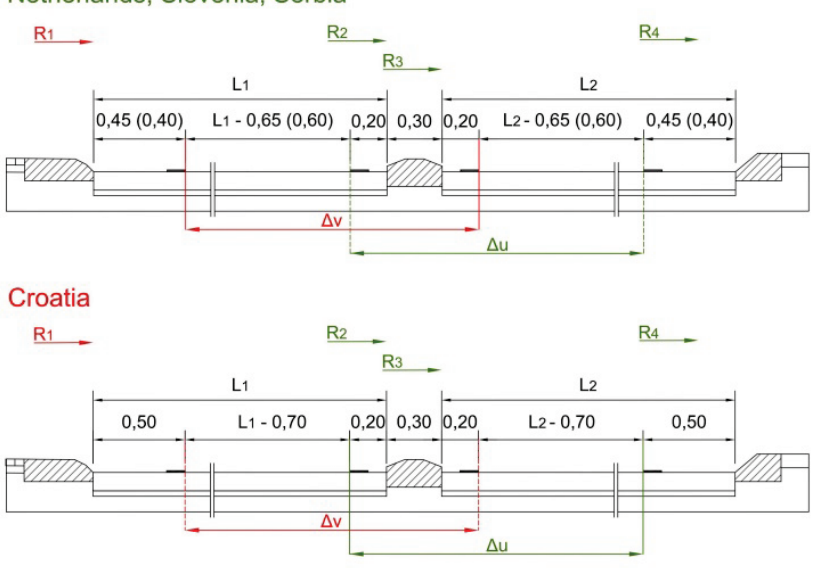

Figure 5 Cross sections of common Dutch [7], Croatian [26], Slovenian [20] and Serbian [25] roundabout variants

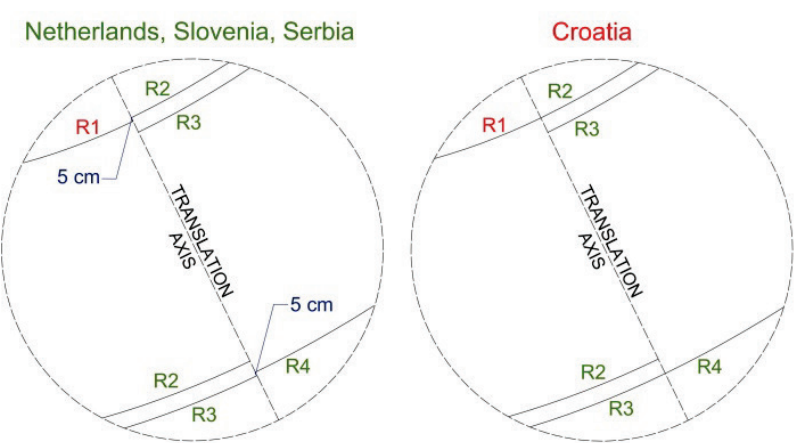

Figure 6 Circular arcs shift [7, 20, 25] and overlapping [26] on translation axis

As mentioned before, Dutch guidelines [7], Slovenian technical specifications [20] and Serbian design manual [25] recommends the use of Rotor and Star roundabout. Turbo block templates for those two roundabout variants are provided only in Dutch guidelines [7].

\subsubsection{Group 2}

According to the German working document [23], turbo block consists of three pairs of circular $\operatorname{arcs}\left(R_{1}, R_{2}\right.$, $R_{3}$ ), and only two centres on the translation axis (Fig. 7).
First centre represents the centre of circular arcs at one side of the translation axis, and second centre represents the centre of circular arcs at the other side of the translation axis. Consequently, German turbo block has no widening at the beginning of the inner circulatory lane i.e. the widths of both circulatory lanes are constant.

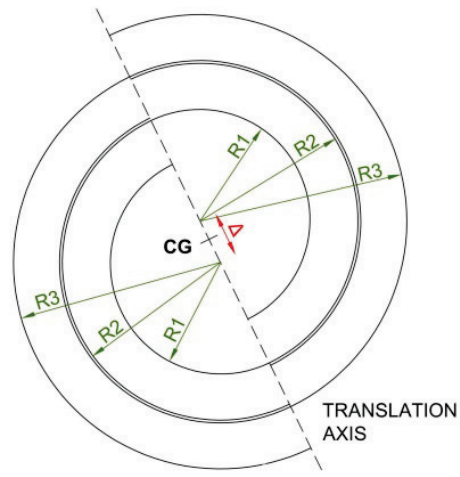

Figure 7 Turbo block elements according to German working document [23]

German regulations on turbo roundabouts [23] do not provide turbo block templates with predetermined dimensions. According to this document, circulatory lane width depends on the size of a roundabout diameter and design vehicle swept path. Recommended values for roundabout diameter range from $45 \mathrm{~m}$ to $70 \mathrm{~m}$, and for circular lane width from $5,0 \mathrm{~m}$ to $6,0 \mathrm{~m}$. Translation axis position should be determined iteratively depending on the position of roundabout approaches and the design vehicle swept path.

\subsection{Other turbo roundabout elements}

After creating a turbo block, remaining turbo roundabout elements can be designed: central island, approaches, and raised mountable lane dividers. As described below, documents considered in this paper define these elements in a different manner (same elements have different purposes), assign different dimensions to them, and provide different guidelines on their geometric design. 


\subsubsection{Central island}

Turbo roundabout central island consists of traversable apron and non-traversable central part (Fig. 8). According to Dutch guidelines [7], traversable apron enables passage of vehicles longer than $22 \mathrm{~m}$ through the inner circulatory lane. Recommended width of traversable apron is $5 \mathrm{~m}$. In Croatian guidelines [26], Slovenian technical specifications [20] and Serbian design manual [25] traversable apron is defined as a surface where special emergency vehicles and regular vehicles in case of emergency can stop. Width of traversable apron recommended by this group of regulations amounts from $2,0 \mathrm{~m}$ to $2,5 \mathrm{~m}$.

As well as for traversable apron, above documents provide different guidelines on design of non-traversable part of central island. According to Dutch guidelines [7], non-traversable part of central island is a roundabout element that is used for placing traffic signs that are cutting of the view of the horizon in direction of travel (roundabout safety requirement). According to Croatian guidelines [26], Slovenian technical specifications [20] and Serbian design manual [25], this element is "irrelevant in terms of traffic operations" and represents the "redundant roundabout space".

In German working document [23], central island is defined as "important turbo roundabout element". More detail data about its function and design are not given.

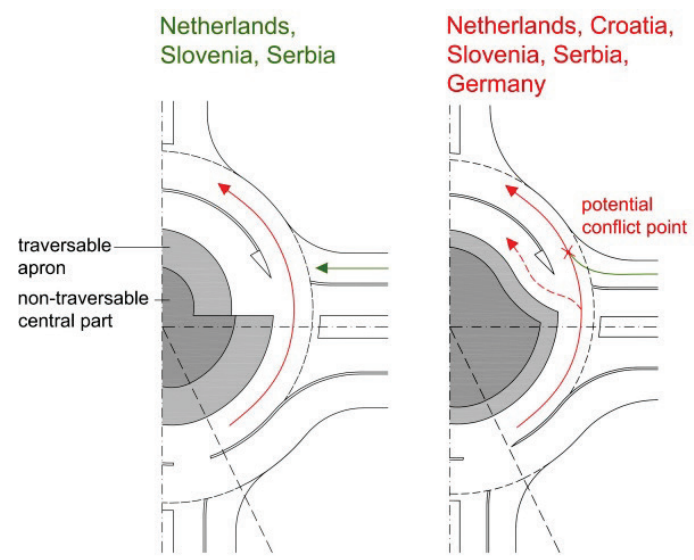

Figure 8 Central apron with flat and spiral beginning

The beginning of traversable apron, i.e. the beginning of inner circulatory lane, can be designed as flat or spiral. In Dutch guidelines [7], application of flat beginning is recommended, because the spiral one is often ambiguous to the drivers that are approaching roundabout entrance, and it consequently leads to the conflict at roundabout circulatory roadway (Fig. 8). In Croatian guidelines [26] and German working document [23] all roundabout examples shown on figures have traversable apron with spiral beginning, and additional instructions on their design are not given. In Slovenian technical specifications [20] and Serbian design manual [25] some of roundabout examples shown in figures are presented with traversable apron with flat beginning, and some with traversable apron with spiral beginning. As well as in Croatian guidelines [26] and German working document [23], additional instructions on their design are not provided.
One thing that should be emphasized in all these documents is that central island shape has great influence on fastest path vehicle speed, which is an important indicator of traffic safety in roundabouts.

\subsubsection{Approaches}

According to Dutch guidelines [7], turbo roundabout approaches should be aligned at "right angles to a roundabout", and because of the rideability of long vehicles these angles should amount to $90^{\circ}$. It should be noted that approaches aligned at $90^{\circ}$ angles are often difficult to plan, especially in a case of reconstruction of existing two-lane roundabouts located at sites with significant spatial limitations. Furthermore, approaches should be designed in a way that the speed of a passenger car while passing through the roundabout does not exceed the maximum recommended value [1]. In Croatian guidelines [26], Slovenian technical specifications [20] and Serbian design manual [25] detail guidelines on roundabout approaches positioning are not provided. According to German working document [23], axis of roundabout approaches should intersect in a roundabout geometric centre, but it is not defined at what angles.

Main parameters that define turbo roundabout approaches are: width of entry and exit lanes, width of splitter islands, and entry and exit radii, i.e. radii of curvature of roadway edges between the roundabout approaches and the circulatory roadway. All these parameters should be chosen on the basis of roundabout size, relevant design vehicle swept path and required driving speed through a roundabout.

In Dutch guidelines [7], Croatian guidelines [26], Slovenian technical specifications [20] and Serbian design manual [25], widths of turbo roundabout entry and exit lanes are not defined. In German working document [23], widths of entry and exit lanes are defined as follows: in a case of single lane entrances and exits, entry lanes are 4,0 $\mathrm{m}$ wide and exit lanes $4,50 \mathrm{~m}$; in a case of two-lane entrances and exits, entry lanes are $3,5 \mathrm{~m}$ wide and exit lanes 4,0 m.

According to Dutch guidelines [7], minimum width of splitter island is $2,5 \mathrm{~m}$. In Croatian guidelines [26], Slovenian technical specifications [20] and Serbian design manual [25] this value is $2,0 \mathrm{~m}$. In German working document [23] splitter island dimensions are not recommended.

According to Dutch guidelines [7], minimum radii of entry and exit curves are $10 \mathrm{~m}$. According to Croatian guidelines [26], Slovenian technical specifications [20] and Serbian design manual [25] minimum radii of entry curves are $12 \mathrm{~m}$, and minimum radii of exit curves $15 \mathrm{~m}$. According to German working document [23] radii of entry curves are between $14 \mathrm{~m}$ and $16 \mathrm{~m}$, and radii of exit curves between $16 \mathrm{~m}$ and $20 \mathrm{~m}$.

\subsubsection{Raised mountable lane dividers}

According to Slovenian authors [4], countries with turbo roundabouts can be divided into these groups: countries in which raised mountable lane dividers are used, and countries in which raised mountable lane dividers are avoided (dismissed). They claim that the 
main reason the latter countries have less satisfactory experiences with turbo roundabouts is because "road marking does not prevent the lane changing" [4]. German author [29] claims that application of mountable lane dividers is not acceptable because of motorcycle safety, winter service and maintenance requirements, and that the absence of these elements does not have great influence on intersection traffic safety and capacity.

Dutch guidelines [7], Croatian guidelines [26], Slovenian technical specifications [20] and Serbian design manual [25] recommend the use of raised mountable lane dividers. According to Fortuijn [1], lane dividers should be designed in the manner that "vehicles can drive over them without damage, while at the same time producing enough discomfort to discourage this behaviour in most cases". His research [16] has shown that lane divider 30 $\mathrm{cm}$ wide and $7 \mathrm{~cm}$ high is optimal. Above mentioned regulations are recommending these dimensions.

On suburban turbo roundabouts application of specially designed traversable beginning on a mountable lane divider is recommended. This element prevents the impermissible traffic flow weaving on circulatory roadway and facilitates the passage of long vehicles through a roundabout (Fig. 9).

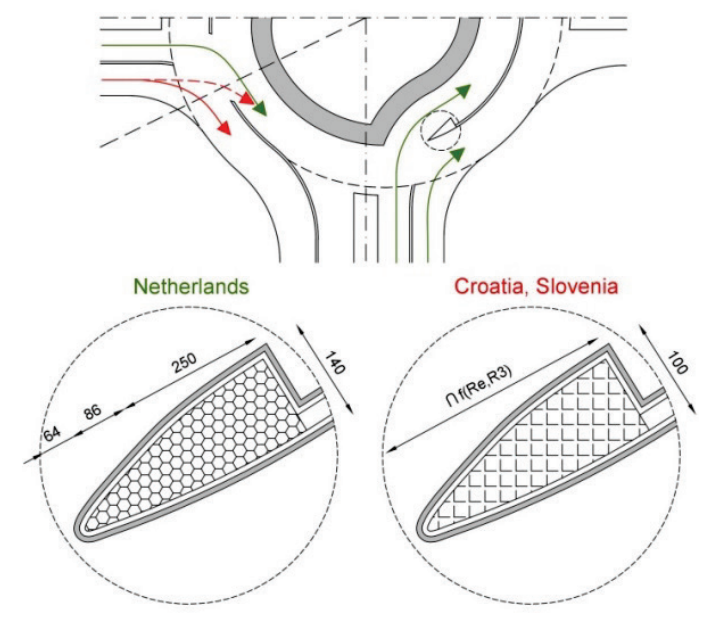

Figure 9 Traversable beginning on a mountable lane divider

According to Dutch guidelines [7], standard length of traversable beginning on mountable lane divider is $4 \mathrm{~m}$. In Croatian guidelines [26] and Slovenian technical specifications [20], length of this roundabout element is not defined; it is only noted that its curvature depends on the applied entry curve radii $\mathrm{R}_{\mathrm{e}}$ and outer circulatory lane inner radii $\mathrm{R}_{3}$. This design approach is substantially better, because the designer can choose an arbitrary length that will precisely accommodate the design vehicle swept path, and at the same time prevent the weaving on the circulatory roadway. In Serbian design manual [25] detail guidelines on traversable lane divider beginning design are not provided.

Opening width at the inner circulatory lane entrance is not defined in any of considered documents. Study [19] has shown that this width depends on the design vehicle swept path, entry and circulatory path radii applied during swept path analyses, minimum clearances, lane divider width and chosen circulatory roadway inner radius.

\subsection{Performance checks}

According to Dutch guidelines [7], Croatian guidelines [26], Slovenian technical specifications [20] and Serbian design manual [25], after designing a turbo roundabout, design vehicle swept path and fastest path vehicle speed analyses must be carried out. If analyses show that applied roundabout elements fulfil both swept path and fastest path vehicle speed requirements, the design solution can be adopted. If not, redefinition of applied elements should be performed.

In design procedure described in German working document [23], design vehicle swept path is the basis for definition of all roundabout elements. Previous studies, carried out on various junction types, have shown that this design approach ensures the usage of optimal dimensions of roundabout elements, as well as safety and comfort during driving [37, 38]. Another feature according to which German working document [23] differs from other regulations considered in this paper is that fastest path vehicle speed analyses are not required. Design procedure described in this document can result with higher driving speeds through a roundabout, but in that case speed can be regulated by traffic signs. This especially refers to roundabouts located at sites with significant spatial limitations where new redesign of roundabout elements (increase in roundabout diameter) often is not possible.

\subsubsection{Horizontal swept path analysis}

Documents presented in this paper set different swept path requirements. According to Croatian guidelines [26], Slovenian technical specifications [20] and Serbian design manual [25] "when conducting a critical turning movement the design vehicle must not track over the traversable central apron, or the $30 \mathrm{~cm}$ wide raised mountable lane dividers placed between the circulatory lanes, and it can track over the traversable beginning on raised mountable lane divider". In Dutch guidelines [7], such behaviour is recommended, but not mandatory. According to German working document [23], while driving through a roundabout design vehicle must not track over the neighbouring lane. In some other regions, for instance in Czech Republic, such behaviour is allowed i.e. long vehicles are, because of insufficient entry, exit and circulatory lanes widths, allowed to drive partially in neighbouring lanes [39].

All considered regulations, except the German working document [23], provide values for the entry path radius, an important input parameter in swept path analysis. According to Dutch guidelines [7], recommended value for the entry path radius is $12 \mathrm{~m}$. According to Croatian guidelines [26], Slovenian technical specifications [20] and Serbian design manual [25], when vehicle is entering the inner circulatory lane, entry path radius of $20 \mathrm{~m}$ should be applied, and when vehicle is entering the outer circulatory lane, entry path radius of $12 \mathrm{~m}$ should be applied. Application of larger entry path radii does not result with significantly greater opening widths of inner circulatory lane, but with wider swept area at circulatory roadway entrance (Fig. 10). 


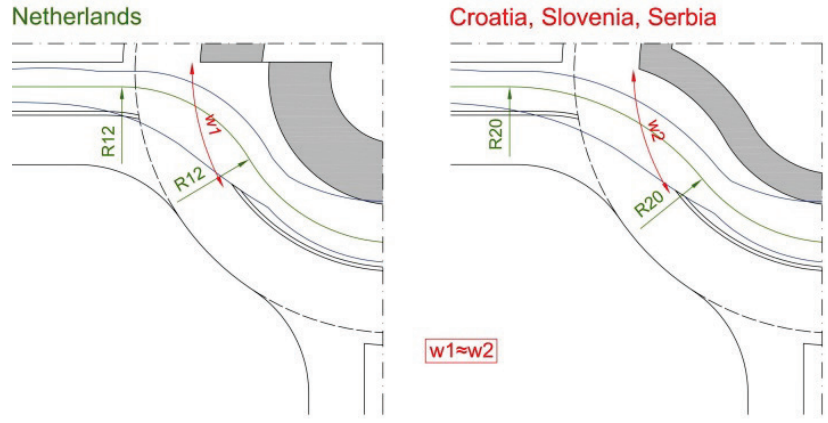

Figure 10 Entry path radii to inner circulatory lane

In German working document [23], additional limitation in swept path analysis is introduced. This limitation is a minimum clearance along design vehicle movement trajectories that provide unhindered passage of vehicles that drive simultaneously on circulatory roadway. Minimum clearance also represents a protective lateral width needed for a long vehicle driver to maintain driving direction. According to this document, lateral distance between the vehicles on the circulatory roadway should be $1,0 \mathrm{~m}$; minimum clearance is therefore $0,50 \mathrm{~m}$. In Appendix IV of Dutch guidelines on turbo roundabouts [7], swept path analysis results for right turn and through movement on standard turbo roundabout are shown. These examples are indicating that in this document minimum clearance is not taken into account. According to appendix D of Croatian general guidelines for roundabout design [31], minimum clearance represents "an additional space for passage of vehicles that do not use path intended by project". Minimum clearance of 0,50 $\mathrm{m}$ (or at least $0,30 \mathrm{~m}$ ) is recommended on all roundabout segments, except on the outer edges of circulatory roadway, where this parameter amounts to $1,0 \mathrm{~m} \mathrm{[31].}$ This approach can lead to oversized roundabout solutions and greater speeds on circulatory roadway. In Slovenian technical specifications [40] and Serbian design manual [25] on general roundabout design, minimum clearance of $1,0 \mathrm{~m}$ is recommended.

\subsubsection{Fastest path vehicle speed analysis}

Fastest path vehicle speed is the speed a passenger car achieves while taking the straightest possible path through a roundabout, in the absence of other vehicles and by not respecting the lane markings on the roadway [41]. Because of raised mountable lane dividers, the fastest path of a passenger car while driving straight through a turbo roundabout has greater deviation than fastest path of a passenger car in a two-lane roundabout. Consequently, driving speeds in turbo roundabouts are lower than those in two-lane roundabouts [17]. Dutch guidelines [7], Croatian guidelines [26], Slovenian technical specifications [20] and Serbian design manual [25] are providing same directions for turbo roundabout fastest path vehicle speed analysis procedure. According to these documents, analysis should be carried out for: through movement, right turn from the outer entry lane and right turn from the inner entry lane. Vehicle fastest paths should always be assigned in respect to potential points of impact and should be placed at the distance of $1 \mathrm{~m}$ from them.
Simple swept path analysis carried out on a standard turbo roundabout of regular size with a passenger car from Dutch regulations [42] showed that $1 \mathrm{~m}$ clearance does not always ensure unhindered passage of a passenger car: while driving straight through a turbo roundabout vehicle was tracking over the outer edges of the roadway (Fig. 11). In other regulations, such as Serbian technical rules [43] and American guidelines [27], larger minimum clearances are recommended. According to [43], minimum clearance from the outer edge of the roadway amounts to $1,5 \mathrm{~m}$, and from the edge of the central island to $2,0 \mathrm{~m}$. According to [27], minimum clearance from the road marking of the splitter island amounts to $1,0 \mathrm{~m}$, and from the outer edge of the roadway and the edge of the central island to $1,5 \mathrm{~m}$. Research [38] has shown that $2 \mathrm{~m}$ clearances result with great curvature of vehicle path i.e. they do not define straightest possible path of a single vehicle through a roundabout. Considering all of the above, optimum value of minimum clearance is $1,5 \mathrm{~m}$.

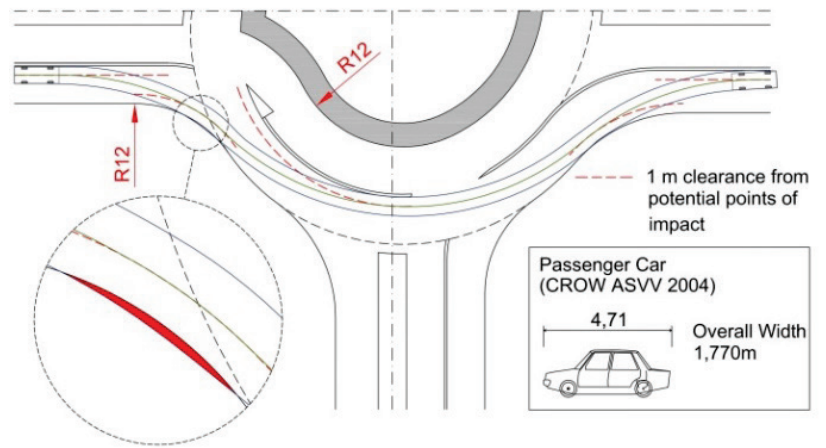

Figure 11 Fastest path vehicle speed analyses

According to $[7,26,20,25]$ vehicle speed on fastest path defined by previous procedure can be calculated with a help of the Eq. (1):

$V=7,4 \cdot \sqrt{R}$

where: $V$ - fastest path vehicle speed $(\mathrm{km} / \mathrm{h}), R$ - fastest path radius $(\mathrm{m})$.

According to Dutch guidelines [7], fastest path vehicle speed through a turbo roundabout should amount to between 37 and $40 \mathrm{~km} / \mathrm{h}$, and according to Croatian guidelines [26], Slovenian technical specifications [20] and Serbian design manual [25], recommended value of this speed is between 35 and $37 \mathrm{~km} / \mathrm{h}$.

\section{Discussion}

Regulations on turbo roundabouts presented in this paper differ in the following: number of turbo roundabout variants, information about relevant design vehicles, dimensions of certain turbo block and cross-section elements, definition of particular roundabout elements, and input parameters in roundabout performance checks.

Despite the previous differences, described turbo roundabout planning procedures are quite similar. In Slovenian technical specifications, Serbian design manual, and Dutch and Croatian guidelines firstly initial roundabout scheme is designed, and then swept path and fastest path vehicle speed analyses are carried out. This 
design approach therefore greatly depends on the quality of performance checks, and gives freedom to the designer on the decision whether the project solution is acceptable or not. Those design procedures consequently can lead to oversized and undersized roundabout solutions because the designer can conclude that chosen roundabout elements are satisfactory if they accommodate the design vehicle swept path in any manner - with lack or extra space for unobstructed passage of relevant design vehicle. Considering the above, it would be advantageous that these documents define more relevant input parameters for swept path analysis, including the detailed instructions for design vehicle choice.

In German working document design vehicle swept path is used not only as a performance check at the end of a design process, but also as a key parameter in geometric design of all turbo roundabout elements. Long term studies performed at the Department for Transportation of the Faculty of Civil Engineering, University of Zagreb $[37,38]$, have confirmed that this design approach ensures the usage of optimal roundabout element dimensions and an unhindered path for the design vehicle through the intersection. As well as in previous group of design procedures, detail guidelines on swept path analysis would significantly contribute to the success of this design procedure.

Another thing that should be emphasized is that swept path requirements significantly depend on alignment of roundabout approaches (non-radial, curvilinear, etc.). Slovenian, Serbian, Dutch and Croatian regulations provide turbo roundabout templates with predetermined turbo block dimensions that refer only to radial approaches, aligned at $90^{\circ}$ angles at circulatory roadway. In engineering practice, application of roundabouts with such "ideal" position of the approaches is rare, especially in a case of intersection reconstruction. Design procedure described in German regulations considers all of previously mentioned positions of roundabout approaches.

\section{Conclusion}

An overview of regulations for turbo roundabout geometric design, valid in Netherlands, Slovenia, Serbia, Croatia and Germany, showed that design procedure described in German regulations significantly differs from other procedures considered in this paper, i.e. that German design procedure, compared to other procedures, results with optimal roundabout element dimensions and can be used in a case of various positions of roundabout approaches.

Considering the above, further studies on turbo roundabout geometry should be based on the design concept recommended by German regulations. During that, input parameters recommended in this paper should be used. Future studies should include the following: (1) definition of new step-by-step turbo roundabout design procedure, based on the rules of design vehicle movement geometry; (2) definition of more relevant input parameters in swept path analysis; (3) definition of relationships between the turbo roundabout radius, design vehicle swept path and circulatory lane width; (4) definition of the influence of various alignments of roundabout approaches on turbo-block dimensions.

\section{References}

[1] Fortuijn, L. G. H. Turbo Roundabouts: Design Principles and Safety Performance. // Journal of the Transportation Research Board. 2096, (2009), pp. 16-24. DOI: 10.3141/209603

[2] Engelsman, J. C.; Uken, M. Turbo Roundabouts as an Alternative to Two Lane Roundabouts. // The challenges of implementing policy? // Proceedings of the $26^{\text {th }}$ Southern African Transport Conference (SATC 2007) / Pretoria, 2007, pp. 581-589.

[3] Giuffrè, O.; Granà, A.; Marino, S. Comparing Performances of Turbo-roundabouts and Double-lane Roundabouts. // Modern Applied Science. 6, 10(2012), pp. 70-79. DOI: 10.5539/mas.v6n10p70

[4] Tollazi, T.; Renčelj, M. Modern and alternative types of roundabouts - state of the art. // Sustainable Urban Development, Proceedings of $9^{\text {th }}$ International Conference on Environmental Engineering / Vilnius, 2014.

[5] Tollazi, T.; Renčelj, M. Comparative Analyse of the Two New Alternative Types of Roundabouts - Turbo and Flower Roundabout. // The Baltic Journal of Road and Bridge Engineering. 9, 3(2014), pp. 164-170. DOl: 10.3846/bjrbe.2014.21

[6] Dirk de Baan. 2015.www.dirkdebaan.nl (10.09.2015)

[7] Turborotondes (Turbo Roundabouts). CROW, Publication No. 257, 2008

[8] Mauro, R.; Branco, F. Comparative Analysis of Compact Multilane Roundabouts and Turbo-Roundabouts. // Journal of Transportation Engineering. 136, 4(2010), pp. 316-322. DOI: 10.1061/(ASCE)TE.1943-5436.0000106

[9] Bastos Silva, A.; Mariano, P.; Pedro Silva, J. Performance Assessment of Turbo-roundabouts in Corridors. // Transport Research Procedia. 10(2015), pp. 124-133. DOl: 10.1061/(ASCE)TE.1943-5436.0000106

[10] Tollazzi, T.; Renčelj, M.; Turnšek, S. New Type of Roundabout: Roundabout with "Depressed" Lanes for Right Turning - "Flower Roundabout". // Promet - Traffic \& Transportation. 23, 5(2011), pp. 353-358. DOI: 10.7307/ptt.v23i5.153

[11] Tollazzi, T.; Jovanović, G.; Renčelj, M. New Type of Roundabout: Dual one-lane roundabouts on two levels with right-hand turning bypases - "Target roundabout". // Promet - Traffic \& Transportation, 25, 5(2013), pp. 475481. DOI: $10.7307 /$ ptt.v25i5.1230

[12] Giuffrè, O.; Guerrieri, M.; Granà, A. Conversion of Existing Roundabouts into Turbo-Roundabouts: Case Studies from Real World. // Journal of Civil Engineering and Architecture. 6, 8(2012), pp. 953-962.

[13] Guerrieri, M.; Corriere, F.; Lo Casto, B.; Rizzo, G. A model for evaluating the environmental and functional benefits of "innovative" roundabouts. // Transportation Research Part D: Transport and Environment. 39, 2015, pp. 1-16. DOI: 10.1016/j.trd.2015.05.004

[14] Mauro, R.; Cattani, M.; Guerrieri, M. Evaluation of the safety performance of turbo roundabouts by means of a potential accident rate model. // The Baltic Journal of Road and Bridge Engineering. 10, 1(2015), pp. 28-38. DOl: 10.3846/bjrbe.2015.04

[15] Vasconcelos, L.; Silva, A.; Seco, A.; Fernandes, P.; Coelho, M. Turboroundabouts: Multicriterion Assessment of Intersection Capacity, Safety, and Emissions. // Transportation Research Record: Journal of the Transportation Research Board. 2402, (2014), pp. 28-37. DOI: $10.3141 / 2402-04$ 
[16] Fortuijn, L. G. H. Turborotonde en turboplein: ontwerp, capaciteit en veiligheid (Turboroundabouts: design, capacity and safety). Doctoral Thesis, Delft, 2012.

[17] Ticali, D.; Corriere, F. Turbo roundabouts: geometric design parameters and performance analysis. // GSTF Journal on Computing (JoC). 2, 1(2012), pp. 227-232. DOl: 10.5176_2010-2283_2.1.155

[18] Bastos Silva, A.; Santos, S.; Gaspar, M. Turbo-Roundabout Use and Design. Universidade de Coimbra. 2013. http://www.dec.uc.pt/ abastos/Outputs/congressos\%20naci naci/Citta2013 turbo.pdf. (15.05.2015).

[19] Chan, S.; Livingston, R. Design Vehicle's Influence to the Geometric Design of Turbo Roundabouts. Teach America. 2014. http://teachamerica.com/RAB14/RAB14papers/ RAB14ppr147_Chan.pdf(15.06.2015).

[20] Krožna križišča s spiralnim potekom krožnega vozišča (Roundabouts with a Spiral Course of the Circulatory Roadway). Ministry of Transport Republic of Slovenia, TSC 03.XXX, draft version, 2011.

[21] Slovenian Experiences with Alternative Types of Roundabouts - "Turbo" and "Flower" Roundabouts. // Proceedings of 8th International Conference on Environmental Engineering / Vilnius, 2011, pp. 1220-1226.

[22] Hinweise zu Turbokreisverkehren (Advisefor Turboroundabouts). FGSV, draft version, 2014.

[23] Arbeitspapier Turbokreisverkehre (Working Document on Turbo Roundabouts). FGSV, 2015.

[24] Die Forschungsgesellschaft für Straßen- und Verkehrswesen (The Research AssociationforRoadsand Transportation). 2015.www.fgsv.de. (01.07.2015).

[25] Priručnik za projektovanje puteva u Republici Srbiji, Dio 5.3 Kružne raskrisnice (Manual for Road Design in Republic of Serbia, Part 5.3 Roundabouts). Serbian Authority for Roads, Beograd, 2012.

[26] Smjernice za projektiranje kružnih raskrižja sa spiralnim tokom kružnog kolnika na državnim cestama (Guidelines for Design of Roundabouts with Spiral Circulatory Roadway on State Roads). Croatian Authority for Roads, Zagreb, 2014.

[27] Roundabouts: An Informational Guide. Second Edition, NCHRP Report 672, Transportation research Board, Washington, D.C., 2010.

[28] Informačního systému výzkumu, experimentálního vývoje a inovací (Research and development and Innovation System of the Czech Republic).2015. www.isvav.cz. (01.07.2015).

[29] Brilon, W. Roundabouts: a State of the Art in Germany. Teach America. 2015. http://www.teachamerica.com/ roundabouts/RA055A_ppr_Brilon.pdf

[30] Aurell, J.; Wadman, T. Vehicle Combinations Based on the Modular Concept. Report No. 1/2007. Volvo Trucks, 2007. http://www.nvfnorden.org/lisalib/getfile.aspx?itemid $=1589$. (20.05.2015).

[31] Smjernice za projektiranje kružnih raskrižja na državnim cestama (Guidelines for Roundabout Design on State Roads). Croatian Authority for Roads, Zagreb, 2014.

[32] Richtlinien für die Anlage von Strassen Teil: Kontenpunkte, Abschnitt 1: Plangleiche Knotenpunkte (RAS-K1) (Guidelines for Road Design, Part: Intersections, Section 1: At-grade intersections).FGSV, Köln, 2001.

[33] Maletin, M.; Andjus, V.; Katanić, J. Tehnička uputstva za planiranje i projektovanje gradske putne mreže (Technical guidelines for urban road network planning and designing). (PGS-M/06), Centre of Civil Engineering, Beograd, 2010.

[34] Rijavec, R. Upit vezan za mjerodavna vozila u Republici Sloveniji. Personal message. (30.09.2015).

[35] Directive 2002/7/EC of the European Parliament and of the Council of 18 February 2002 amending Council Directive 96/53/EC laying down for certain road vehicles circulating within the Community the maximum authorised weights in international traffic and the maximum authorised weights in international traffic, OJ L 67.

[36] Eenheid in rotondes (Uniformity in Roundabouts). CROW Publication No. 126, 1998.

[37] Stančerić, I. Teorijske postavke oblikovanja četverokrakih čvorišta u razini na načelima geometrije kretanja vozila (Theoretical Approach of Design of Four-Leg Intersections at Grade Based on Rules of Vehicle Movement Geometry).Doctoral Thesis, Faculty of Civil Engineering of University of Zagreb, Zagreb, 2011.

[38] Ahac, S. Oblikovanje izvangradskih kružnih raskrižja na načelima geometrije kretanja vozila (Design of Suburban Roundabouts Based on the Rules of Vehicle Movement Geometry).Doctoral Thesis, Faculty of Civil Engineering of University of Zagreb, Zagreb, 2014.

[39] Tollazzi, T. Alternative Types of Roundabouts - An Informational Guide. Springer Tracts on Transportation and Traffic, Switzerland, 2015.

[40] Krožna križišča (Roundabouts). Ministry of Transport Republic of Slovenia, TSC 03.341, 2011.

[41] Pilko, H.; Brčić, D.; Šubić, N. Study of vehicle speed in the design of roundabouts. // Građevinar. 66, 5(2014), pp. 407416. DOI: $10.14256 / J C E .887 .2013$

[42] Aanbevelingen voor verkeersvoorzieningen binnen de bebouwde kom (Recommendations on traffic in urban areas). CROW, Publication No. 723, 2004.

[43] Pravilnik o uslovima koje sa aspekta bezbednosti saobraćaja moraju da ispunjavaju putni objekti i drugi elementi javnog puta (Rules on traffic safety of traffic facilities and other public road elements). Official Gazette RS 50(2011).

\section{Authors' addresses}

Tamara Džambas, assistant

Faculty of Civil Engineering of University of Zagreb Kačićeva 26, 10000 Zagreb, Croatia

E-mail: tdzambas@grad.hr

Saša Ahac, assistant professor

Faculty of Civil Engineering of University of Zagreb Kačićeva 26, 10000 Zagreb, Croatia

E-mail: sahac@grad.hr

Vesna Dragčević, full professor

Faculty of Civil Engineering of University of Zagreb

Kačićeva 26, 10000 Zagreb, Croatia

E-mail: vesnad@grad.hr 